32 Tibbo $\mathrm{P}$, Swainson J, Chue $\mathrm{P}$, LeMelledo J-M. Prevalence and relationship to delusions and hallucinations of anxiety disorders in schizophrenia. Depress Anxiety 2003; 17: 65-72.

33 Kessler RC, Merikangas KR, Berglund P, Eaton WW, Koretz SD, Walters EE. Mild disorders should not be excluded from the DSM-V. Arch Gen Psychiatry 2003, 60: 1117-22

34 Kingsep $P$, Nathan $P$, Castle D. Cognitive behavioural group treatment for social anxiety in schizophrenia. Schizophr Res 2003; 63: 121-9.

35 Gumley A, O'Grady M, Power K, Schwannauer M. Negative beliefs about self and illness: a comparison of individuals with psychosis with and without comorbid social anxiety disorder. Aust N Z J Psychiatry 2004; 38: 960-4.

36 Stein $M$, Tancer $M$, Gelernter $C$, Vittone $B$, Uhde T. Major depression in patients with social phobia. Am J Psychiatry 1990; 147: 637-9.

37 Schneier F, Johnson J, Horing C, Liebowitz A, Weissman M. Social phobia: comorbidity and morbidity in an epidemiological sample. Arch Gen Psychiatry 1992; 49: 282-8.

38 Wittchen $\mathrm{H}-\mathrm{U}$, Stein $\mathrm{M}$, Kessler R. Social fears and social phobia in a community sample of adolescents and young adults: prevalence, risk factors and comorbidity. Psychol Med 1999; 29: 309-23.
39 Siris SG. Depression and schizophrenia. In Schizophrenia (eds SR Hirsch, DR Weinberger): 128-45. Blackwell, 1995.

40 Freeman D, Garety PA, Bebbington P, Slater M, Kuipers E, Fowler D, et al The psychology of persecutory ideation. II: a virtual reality experimental study. J Nerv Ment Dis 2005; 193: 309-15.

41 Freeman $D$, Garety $P A$, Bebbington $P E$, Smith $B$, Rollinson R, Fowler $D$, et al. Psychological investigation of the structure of paranoia in a non-clinical population. Br J Psychiatry 2005; 186: 427-35.

42 Kirkbride JB, Morgan C, Fearon P, Dazzan P, Murray RM, Jones PB. Neighbourhood-level effects on psychoses: re-examining the role of context. Psychol Med 2007; 37: 1413-25.

43 Morgan C, Kirkbride J, Leff J, Craig T, Hutchinson G, McKenzie K, et al. Parental separation, loss and psychosis in different ethnic groups: a casecontrol study. Psychol Med 2007; 37: 495-503.

44 de Wilde A, Rapee RM. Do controlling maternal behaviours increase state anxiety in children's responses to a social threat? A pilot study. J Behav Ther Exp Psychiatry 2008; 39: 526-37.

\title{
Hope to live
}

Gethin Morgan

Hope to continue living is rarely irrevocably lost. Even in mental illness and depths of despair hope is still there waiting to return. In chronic physical disability hope and comfort can be regained through seemingly trivial symptomatic improvement. It can survive in apparently hopeless situations. So surely we should fan whatever embers of hope remain, and never confirm despair. To begin, just listen with realistic optimism for as long as it takes. It soon becomes clear that such hope can indeed spring eternal in the human breast; and from it flows a renewed conviction that life is after all worthwhile. 